\title{
An Empirical Analysis of determinants for Prototype Mass Production and Prototype Quality Level: The Case of The Hardware Start-up
}

\author{
*Suneung Kim, Dept. of Smart Convergence Consulting, Hansung University, ks013, South Korea, \\ kseksj@naver.com \\ Sooyoung Park, Meister one Co.,Ltd,, 309-12 Techno2-ro, Yoosung-gu, Daejeon, 34134, South Korea \\ Yenyoo You, Dept. of Smart Convergence Consulting, Hansung University, ks013, South Korea \\ ${ }^{*}$ Corresponding author
}

\begin{abstract}
The purpose of this research is to identify the factors affecting the prototype mass production of Start-up companies, and to confirm the mediating effect of the quality level of prototypes on the prototype mass production, and to provide directions for the company's new product development activities. The target of this research was selected as the person in charge of new product development who best grasps the matters related to new products, and the questionnaire was written by the Likert scale was conducted online. The data were empirically analyzed using SPSS (Statistical Package for Social Science) statistics package. The analysis of frequency, reliability, validity, and regression analysis were performed. As a result of this research, the effect of Characteristic of Start-up on Prototype Mass Production was analyzed, and at the same time, the mediating effect of Prototype Quality Level on Prototype Mass Production was analyzed. The results of regression analysis and parameter verification are as follows. First, as Characteristic of Start-up, Organizational Convergence Level, Similar Product Manufacturing experience, and Utilization Level of Government Support was found to have a positive $(+)$ effect on Prototype Mass Production. Next, as Characteristic of Start-up, Organizational Convergence Level, Similar Product Manufacturing experience, and Utilization Level of Government Support were found to have a positive (+) effect on Prototype Quality Level. Finally, in the relationship between Characteristic of Start-up and Prototype Mass Production, it was verified that Prototype Quality Level is mediated as a partial mediating and complete mediating. Characteristic of Start-up is important for Prototype Mass Production, and the mediating effect of Prototype Quality Level has been verified.
\end{abstract}

Keywords: Start-up, Hardware Start-up, Prototype, Quality of Prototype, New Product Development. Received: 14.12.2020 $\quad$ Accepted: 05.01.2021 $\quad$ Published: 07.02.2021

\section{INTRODUCTION}

The "fourth industrial revolution" technology-based start-ups can be a major pillar of employment expansion by creating a new line of work that replaces or expands the existing market, as labor demand and jobs are expected to be decreased due to the rapid development of production methods. In response, not only the government ministries but also the private sectors are focusing on promoting the revitalization of Start-ups by operating various programs to help them find and commercialize startups.[1] Start-up is generally a term meaning "corporate at the start-up stage based on high-tech" at home and abroad. An Organizations looking to create new products or services in extreme uncertainty can be viewed as start-ups of any size or type of organization if conditions are met [2]. In other words, it means that a start-up company that seeks new markets and business opportunities by grafting advanced technologies based on new ideas.[3] some studies have been conducted on the success factors of Korean companies in developing new product, but there is little research on Start-ups. Therefore, this research was intended to empirically analyze factors that the mass production of prototypes of Start-up companies, and to confirm the mediating effect of the quality level of prototypes on the mass production of prototypes.

\section{MATERIALS AND METHODS}

\subsection{Hardware start-up}

Hardware start-ups are manufacturing-based start-ups that produce and sell high-tech products, and although they are based on traditional manufacturing, they differentiate software containing ideas and 
innovations into weapons. Hardware start-ups are growing rapidly in China and major advanced countries, with Silicon Valley in the U.S.[4].

\subsubsection{Organizational Convergence Level}

Standard In order for a clear definition of product specifications to be made, it is important for the design and design sectors, the production sectors, the marketing sectors, and even the supplier and customer participation to be important from the development stage[5] that marketing strategies are needed as a whole departments rather than a single department in coordinating and integrating corporate resources [6].

\subsubsection{Similar Product Manufacturing Experience}

In research on the performance of new product development, many people view that knowledge assets serve as leverage in gaining competitive advantage $[7,8]$ because accumulating knowledge based on experience can lead to improved efficiency, which can lead to repeated past successes at least in the short term $[9,10]$. The ability to acquire knowledge faster than other competing organizations is the only way to strengthen the organization's continued competitiveness [11].

\subsubsection{Utilization Level of Government Support}

It is found that the government's funding has a positive effect on the employment increase of the beneficiary [12,13] or increased the productivity and employment of SMEs at the same time [14]. It was also confirmed that R\&D expenditure was promoted [15] and had a positive effect on technology development performance centered on patent applications [16].

2.2. Prototype Quality Level

Quality refers to the overall composition of the characteristics of marketing technology, manufacturing, and safety that meet consumer expectations in the use of a product or service. Among the conditions that consumers require, two important factors are the actual use of the product or service and the selling price [17]. Quality management is a collection of all means used to realize and realize quality standards, and quality is the suitability for use [18].

\subsection{Prototype Mass Production}

\subsubsection{Prototype}

The definition of a prototype differs slightly by field. In the engineering field, only models that are applicable to production with considerable degree of completion are called prototypes, and other simple models are expressed as models or experimental works [19].

\subsubsection{Mass Production}

In the pre-production stage, the focus is on designing and optimizing processes to find solid process conditions and ensure long-term production reliability. It is argued that the completion of the development of a new product is to release and provide a product that satisfies the customer due to stable mass production in production. In the developing new product, the production of a prototype and mass production of the prototype are important concepts that differentiate the success and failure of new product development [20,21].

\subsection{The Research model and Hypothesis}

\subsubsection{Research model}

This research examines the causal relationship between the characteristics of the Start-up and the mass production performance of the prototype in the process of developing new product. Next, this research seeks to empirically analyze the mediated effects of prototype quality levels in the relationship between the prototype quality level and the prototype mass production performance. Based on previous studies, Organizational Convergence Level, Similar Product Manufacturing Experience, and Utilization Level of Government Support were designated as independent variables, and Prototype Mass Production was designated as dependent variables. Prototype quality level was designated as a parameter in the relationship between characteristic of start-up and the effect of prototype mass production. Based on these preceding studies, a research hypothesis was established to empirically analyze the impact relationship to increase the mass production performance of prototypes in the process of developing new product by Start-ups. The research model is as follows [Figure 1]. 


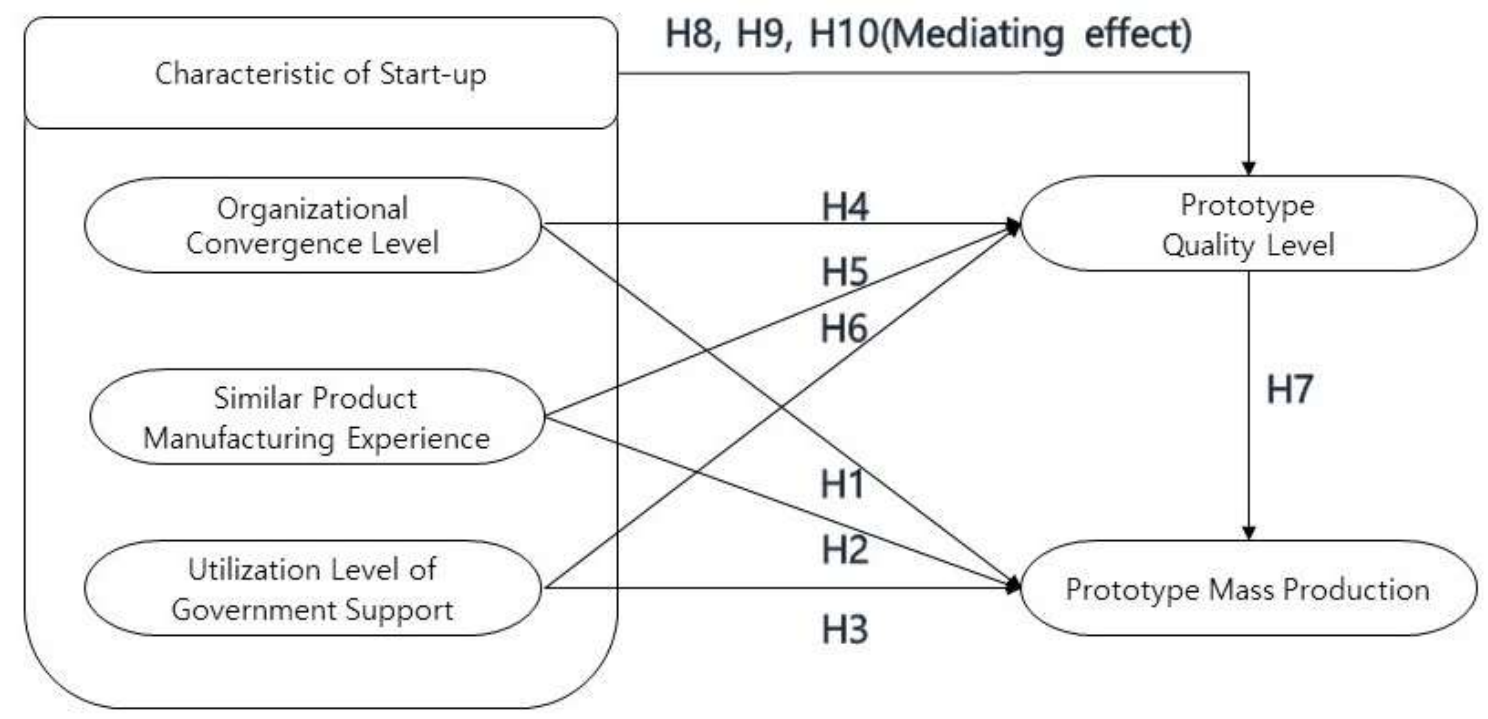

Figure 1 The Research Model

2.4.2. Research Hypothesis

[Figure 1] The hypothesis on the relationship of impact of Start-up characteristics on the performance of Prototype Mass Production was established. In addition, as a hypothesis of the effect of the prototype quality level in the relationship between start-up characteristics and prototype mass production, the effect of the quality level is hypothesized as a parameter.

H1. The Organizational Convergence Level will have a positive effect on the Prototype Mass Production.

H2. The Similar Product Manufacturing Experience will have a positive effect on the Prototype Mass Production.

H3. The Utilization of Government Support will have a positive effect on the Prototype Mass Production. H4. The Organizational Convergence Level will have a positive effect on Prototype Quality Level.

H5. The Similar Product Manufacturing Experience will have a positive effect on Prototype Quality Level.

H6. The Utilization of Government Support will have a positive effect on Prototype Quality Levels.

H7. The Quality Level of Prototype will have a positive effect on the Prototype Mass Production.

H8. The influence of Organizational Convergence Level on the Prototype Mass Production will be mediated by the Prototype Quality Level.

H9. The influence of Similar Product Manufacturing Experience on the Prototype Mass Production will be mediated by the Prototype Quality Level.

H10. The Utilization of Government Support on the Prototype Mass Production will be mediated by the Prototype Quality Level.

\subsubsection{Operational Definition of Variables}

The definition of individual variables used in this research is as [Table1].

Table1 Design of test problems

\begin{tabular}{|c|c|c|c|c|}
\hline $\begin{array}{l}\text { Evaluation } \\
\text { items }\end{array}$ & $\begin{array}{l}\text { Measurement } \\
\text { variable }\end{array}$ & Operational definition & $\begin{array}{l}\text { Configure } \\
\text { questionnair } \\
\text { e }\end{array}$ & Researcher \\
\hline \multirow{3}{*}{$\begin{array}{l}\text { Characterist } \\
\text { ic } \\
\text { Of Start-up }\end{array}$} & $\begin{array}{l}\text { Organization } \\
\text { al } \\
\text { Convergence } \\
\text { Level }\end{array}$ & $\begin{array}{l}\text { Degree of mutual cooperation in } \\
\text { information transfer and problem } \\
\text { solving between marketing dept. with } \\
\text { R\&D dept. }\end{array}$ & 4 questions & $\begin{array}{l}\text { Olson et } \\
\text { al.(2001), } \\
\text { Song and } \\
\text { Parry(1993), }\end{array}$ \\
\hline & $\begin{array}{l}\text { Similar } \\
\text { Product } \\
\text { Manufacturin } \\
\text { g Experience }\end{array}$ & $\begin{array}{l}\text { Level of product production experience } \\
\text { in case of companies involved in } \\
\text { prototype production }\end{array}$ & 4 questions & $\begin{array}{l}\text { saxton(1996 } \\
\text { ), } \\
\text { Larson(1997 } \\
\text { ), } \\
\text { Moorman } \\
\text { and } \\
\text { Miner(1997) }\end{array}$ \\
\hline & Utilization of & The degree of utilization of government & 4 questions & Park, C. R. \\
\hline
\end{tabular}




\begin{tabular}{|c|c|c|c|c|}
\hline & $\begin{array}{l}\text { Government } \\
\text { Support }\end{array}$ & $\begin{array}{l}\text { support for prototype production of } \\
\text { start-up }\end{array}$ & & $\begin{array}{l}\text { etc.(2009), } \\
\text { Lee, Y. W. } \\
\text { etx(2009), }\end{array}$ \\
\hline $\begin{array}{l}\text { Prototype } \\
\text { Quality } \\
\text { Level }\end{array}$ & $\begin{array}{l}\text { Prototype } \\
\text { Quality Level }\end{array}$ & $\begin{array}{l}\text { Quality level of manufactured } \\
\text { prototypes }\end{array}$ & 4 questions & $\begin{array}{l}\text { Juran(1974) } \\
\text { Cooper and } \\
\text { Kleinshmidt( } \\
\text { 1987) } \\
\text { Song\&Parry( } \\
\text { 1994) }\end{array}$ \\
\hline $\begin{array}{l}\text { Prototype } \\
\text { Mass } \\
\text { Production }\end{array}$ & $\begin{array}{l}\text { Prototype } \\
\text { Mass } \\
\text { Production }\end{array}$ & $\begin{array}{l}\text { Indicates whether the prototype has } \\
\text { reached the level of mass production at } \\
\text { the time of completion of production. }\end{array}$ & 4 questions & $\begin{array}{l}\text { Keller(1986) } \\
\text { 'Tishler et al. } \\
\text { (1996), } \\
\text { Cooper and } \\
\text { Kleinschmidt } \\
\text { (1996) }\end{array}$ \\
\hline
\end{tabular}

\section{Results and Discussion}

\subsection{Empirical Results}

To demonstrate the hypotheses presented in this chapter, empirical analysis was conducted by the Statistical Package for Social Science (SPSS). Empirical analysis such as frequency, reliability, feasibility, and correlation, and etc. was performed.

\subsubsection{Demographic characteristics analysis}

The 830 copies of the survey were distributed to collect 148 copies. A total of 136 samples were used in the research, except for questionnaires with insincere or inconsistent responses. According to the gender of the respondents, 117 (86 percent) were male respondents, while 19 (14 percent) were female respondents. According to the age of the survey respondents, 22 respondents (17\%) were aged 20 to 29 , 41 respondents (31\%) were aged 30 to 39,47 respondents (35\%) were aged 40 to 49,18 respondents (14\%) were aged 50 to 59 and 5 respondents (4\%) were aged 60 or older. The history of respondents' companies had 15 respondents ( 13 percent) in less than a year, 30 (24 percent) in two to three years, 33 (27 percent) in three to five years, 17 (14 percent) in five to seven years, and 37 others ( 22 percent). The number of employees was One employee was $14(11 \%)$, two to five were $48(36 \%)$, six to 10 were 29 (22\%), and more than 10 were $41(31 \%)$.

\subsubsection{Reliability analysis and Exploratory factor analysis}

A reliability analysis and exploratory factor analysis of individual measurement variables were performed to verify the collected data. As shown in [Table 2], the analysis confirmed that there was no problem with the reliability and validity of all factors. The reliability analysis of each variable confirms that the Cronbach's Alpha coefficient for each configuration concept was 0.8 or higher, indicating that there were no internal consistency-related problems.

Table2. Exploratory factor analysis and Reliability analysis

\begin{tabular}{|c|c|c|c|c|c|c|c|}
\hline \multirow{2}{*}{$\begin{array}{l}\text { Measureme } \\
\text { nt item }\end{array}$} & \multicolumn{5}{|c|}{$\begin{array}{cc}\text { Exploratory factor } \\
\text { Discriminant validity) }\end{array}$} & \multirow{2}{*}{$\begin{array}{l}\text { Commonalit } \\
\text { y }\end{array}$} & \multirow{2}{*}{\begin{tabular}{|l}
$\begin{array}{l}\text { Reliability } \\
\text { analysis }\end{array}$ \\
$\begin{array}{l}\text { Cronbach' } \\
\text { s alpha }\end{array}$
\end{tabular}} \\
\hline & $\begin{array}{l}\text { convergenc } \\
\text { e }\end{array}$ & $\begin{array}{l}\text { similar } \\
\text { experienc } \\
\mathrm{e}\end{array}$ & $\begin{array}{l}\text { governmen } \\
\text { t support }\end{array}$ & $\begin{array}{l}\text { quality } \\
\text { level }\end{array}$ & $\begin{array}{l}\text { mass } \\
\text { productio } \\
\mathrm{n}\end{array}$ & & \\
\hline $\begin{array}{l}\text { convergence } \\
1\end{array}$ & $\mid 888$ & .141 & .000 & .149 & .165 & .859 & \multirow{4}{*}{.937} \\
\hline $\begin{array}{l}\text { convergence } \\
4\end{array}$ & .876 & .160 & .055 & .147 & .231 & .872 & \\
\hline $\begin{array}{l}\text { convergence } \\
3\end{array}$ & .873 & .179 & .035 & .128 & .211 & .856 & \\
\hline $\begin{array}{l}\text { convergence } \\
2\end{array}$ & .827 & .149 & -.024 & .226 & .194 & .795 & \\
\hline $\begin{array}{l}\text { similar } \\
\text { experience2 }\end{array}$ & .205 & .857 & .063 & .215 & .149 & .848 & \multirow{2}{*}{.904} \\
\hline $\begin{array}{l}\text { similar } \\
\text { experience3 }\end{array}$ & .133 & .804 & .170 & .205 & .175 & .766 & \\
\hline
\end{tabular}




\begin{tabular}{|c|c|c|c|c|c|c|c|}
\hline $\begin{array}{l}\text { similar } \\
\text { experience1 }\end{array}$ & .196 & .777 & .112 & .269 & .118 & .741 & \\
\hline $\begin{array}{l}\text { similar } \\
\text { experience4 }\end{array}$ & .126 & .770 & .202 & .276 & .219 & .773 & \\
\hline $\begin{array}{l}\text { government } \\
\text { support2 }\end{array}$ & .022 & .088 & .868 & .083 & .105 & .780 & \multirow{4}{*}{.889} \\
\hline $\begin{array}{l}\text { government } \\
\text { support3 }\end{array}$ & -.059 & .153 & .849 & .177 & .116 & .792 & \\
\hline $\begin{array}{l}\text { government } \\
\text { support4 }\end{array}$ & .028 & .207 & .838 & .045 & .102 & .758 & \\
\hline $\begin{array}{l}\text { government } \\
\text { support1 }\end{array}$ & .062 & .015 & .813 & .136 & .148 & .705 & \\
\hline $\begin{array}{l}\text { quality } \\
\text { level1 }\end{array}$ & .119 & .181 & .165 & .832 & .120 & .780 & \multirow{4}{*}{.884} \\
\hline $\begin{array}{l}\text { quality } \\
\text { level3 }\end{array}$ & .219 & .274 & .152 & .754 & .129 & .732 & \\
\hline $\begin{array}{l}\text { quality } \\
\text { level2 }\end{array}$ & .272 & .235 & .148 & .738 & .252 & .759 & \\
\hline $\begin{array}{l}\text { quality } \\
\text { level4 }\end{array}$ & .135 & .382 & .068 & .734 & .215 & .753 & \\
\hline $\begin{array}{l}\text { mass } \\
\text { production1 }\end{array}$ & .235 & .195 & .062 & .058 & .822 & .776 & \multirow{4}{*}{.858} \\
\hline $\begin{array}{l}\text { mass } \\
\text { production3 }\end{array}$ & .222 & .158 & .167 & .246 & .776 & .765 & \\
\hline $\begin{array}{l}\text { mass } \\
\text { production2 }\end{array}$ & .224 & .041 & .290 & .149 & .726 & .685 & \\
\hline $\begin{array}{l}\text { mass } \\
\text { production4 }\end{array}$ & .154 & .259 & .084 & .213 & .724 & .668 & \\
\hline Eigen-value & 3.459 & 3.191 & 3.129 & 2.881 & 2.804 & & \\
\hline $\begin{array}{ll}\% & \text { of } \\
\text { Variance }\end{array}$ & 17.293 & 15.956 & 15.643 & 14.405 & 14.022 & & \\
\hline $\begin{array}{l}\% \text { of } \\
\text { Accumulate } \\
d\end{array}$ & 17.293 & 33.249 & 48.892 & 63.297 & 77.319 & & \\
\hline
\end{tabular}

Kaiser-Meyer-Olkin Measure of Sampling Adequacy: .876

Bartlett's test of sphericity: Approx. Chi-Square: $1988.380, \mathrm{df}=190, \mathrm{P},<0.000$

3.1.3. Correlation analysis

Correlation analysis shows the relevance of variables by presenting the strength of the relationship between the measurement variables used in the pre-implementation research of hypothesis testing. According to [Table 3], similar experience shows a high correlation with the quality level as .629**, and mass production shows a relatively high correlation with the convergence and quality level as $.505^{* *}$ compared to other variables.

Table3. Results of Correlation Analysis

\begin{tabular}{l|l|l|l|l|l|l|l|l}
\hline & $\mathrm{N}$ & Mean & $\begin{array}{l}\text { Standar } \\
\mathrm{d} \\
\mathrm{n}\end{array}$ & $\begin{array}{l}\text { conviatio } \\
\mathrm{e}\end{array}$ & $\begin{array}{l}\text { quality } \\
\text { level }\end{array}$ & $\begin{array}{l}\text { similar } \\
\text { experienc } \\
\mathrm{e}\end{array}$ & $\begin{array}{l}\text { governme } \\
\text { nt support }\end{array}$ & $\begin{array}{l}\text { mass } \\
\text { productio } \\
\mathrm{n}\end{array}$ \\
\hline $\begin{array}{l}\text { convergenc } \\
\mathrm{e}\end{array}$ & 136 & 3.5974 & .91751 & 1 & $.463^{* *}$ & $.422^{* *}$ & .107 & 0.505 \\
\hline $\begin{array}{l}\text { quality } \\
\text { level }\end{array}$ & 136 & 3.7923 & .76410 &. $\mathbf{4 6 3 ^ { * * }}$ & 1 & $.629^{* *}$ & $.334^{* *}$ & $.473^{* *}$ \\
\hline $\begin{array}{l}\text { similar } \\
\text { experience }\end{array}$ & 136 & 3.7610 & .78697 & $\mathbf{. 4 2 2 ^ { * * }}$ & $\mathbf{. 6 2 9 ^ { * * }}$ & 1 & $.335^{* *}$ & $.355^{* *}$ \\
\hline $\begin{array}{l}\text { governmen } \\
\text { t support }\end{array}$ & 136 & 3.3272 & .96921 & $\mathbf{. 1 0 7}$ & $\mathbf{. 3 3 4 ^ { * * }}$ & $\mathbf{. 3 3 5 ^ { * * }}$ & 1 & $.355^{* *}$ \\
\hline
\end{tabular}




\begin{tabular}{l|l|l|l|l|l|l|l|l}
$\begin{array}{l}\text { mass } \\
\text { production }\end{array}$ & 136 & 3.6121 & .81185 & $\mathbf{. 5 0 5}$ & $\mathbf{. 5 0 5}$ & $\mathbf{. 4 7 3}$ & $\mathbf{. 3 5 5 ^ { * * }}$ & 1 \\
\hline
\end{tabular}

\subsubsection{Hypothesis test result}

Multiple regression analysis was performed through SPSS for the verification of hypotheses. [Table4] Results show that there is no problem in multi-recovery analysis as the results of Dubin-Watson are close to the baseline of 2, and the variance expansion coefficient (VIF) is below the baseline of 10, it was confirmed that there is no multicollinearity among variables. Looking at the results of the multi-recovery analysis conducted, the verification of hypotheses H1, H2 and H3 confirmed that Start-up Characteristics have positive effects on Prototype Mass Production. Verification of hypotheses H4, H5 and H6 confirmed that Start-up Characteristics have positive effects on the Prototype Quality Level. Verification of Hypothesis H7 confirmed that Prototype Quality Level have positive effects on Prototype Mass Production.

Table4. Results of Multi- regression Analysis Results

\begin{tabular}{l|l|l|l|l|l|l|l}
\hline Hypothesis & Constructs & $\mathrm{B}$ & $\beta$ & $\mathrm{t}$ & $\mathrm{p}$-value & $\mathrm{VIF}$ & Results \\
\hline & (Constant) & .836 & & 2.654 & .009 & & \\
\hline $\mathrm{H} 1$ & convergence & .337 & .381 & 5.064 & .000 & 1.219 & accept \\
\hline $\mathrm{H} 2$ & $\begin{array}{l}\text { similar } \\
\text { experience }\end{array}$ & .241 & .233 & 2.937 & .004 & 1.358 & accept \\
\hline $\mathrm{H} 3$ & $\begin{array}{l}\text { government } \\
\text { support }\end{array}$ & .198 & .236 & 3.260 & .001 & 1.128 & accept \\
\hline
\end{tabular}

R2=387, Adjusted R2=.373, F=27.737( $\mathrm{p}=<.001)$, Durbin-Watson=1.907, Dependent variable: mass production

\begin{tabular}{l|l|l|l|l|l|l|l}
\hline & (Constant) & .929 & & 3.348 & .001 & & \\
\hline $\mathrm{H} 4$ & convergence & .205 & .246 & 3.499 & .001 & 1.219 & accept \\
\hline $\mathrm{H} 5$ & $\begin{array}{l}\text { similar } \\
\text { experience }\end{array}$ & .461 & .475 & 6.389 & .000 & 1.358 & accept \\
\hline $\mathrm{H} 6$ & $\begin{array}{l}\text { government } \\
\text { support }\end{array}$ & .117 & .149 & 2.198 & .030 & 1.128 & accept \\
\hline
\end{tabular}

$\mathrm{R} 2=.463$, Adjusted R2=.450, F=37.888( $\mathrm{p}=<.001)$, Durbin-Watson=1.766, Dependent variable: quality level

\begin{tabular}{l|l|l|l|l|l|l|l}
\hline & (Constant) & 1.577 & & 5.147 & .000 & & \\
\hline H7 & quality level & .537 & .505 & 6.773 & .000 & & accept \\
\hline
\end{tabular}

R2=.255, Adjusted R2=.249, $\mathrm{F}=45.877(\mathrm{p}=<.001)$, Durbin-Watson=1.791, Dependent variable: mass production

\subsubsection{Mediated effect analysis}

A mediated regression analysis was performed to verify the hypothesis that the quality of the prototype will play a mediating role in the relationship between the characteristics of a Start-up on the prototype mass production. The results are as below [Table 5].

Specifically, in first step, the Organizational Convergence Level $(\beta=.246)$, Similar Product Manufacturing Experience ( $\beta=.475)$, and Utilization of Government Support $(\beta=.149)$ all have a positive effect on the quality level as Start-up characteristics statistically. In step 2, the Organizational Convergence Level $(\beta=.381)$, Similar Product Manufacturing Experience $(\beta=.233)$, and Utilization of Government Support ( $\beta=.236$ ) all had a positive effect on the Prototype Mass Production statistically. In the last three stages, the quality level, a parameter, was found to have a positive effect on Prototype Mass Production with a $99 \%$ confidence level $(\beta=.191)$, which satisfied the condition.

The standardized regression coefficient values of the three independent variables, the Organizational Convergence Level $(\beta=.334)$ and the Utilization of Government Support $(\beta=.208)$, are the Organizational Convergence Level of the second stage $(\beta=.381)$, and the Utilization of Government Support $(\beta=.236)$, so it can be identified that there is a mediating effect.

More specifically, in step 3, the Quality Level of the Prototype was found to have an effect on the Prototype Mass Production $(\beta=.191)$, so it was found that there is a partial mediating effect on the Organizational Convergence Level and Utilization of Government Support. In the case of Similar Product Manufacturing Experience, it was found that there is a complete mediating effect on the Prototype Mass Production. 
Table5. Summary of Effect Relationship Analysis Collaboration Among Consultants Effect on Consulting Utilization

\begin{tabular}{|c|c|c|c|c|c|c|c|c|}
\hline \multirow{3}{*}{ model } & \multicolumn{2}{|c|}{ Step1 } & \multicolumn{2}{|c|}{ Step2 } & \multicolumn{2}{|c|}{ Step3 } & \multirow{2}{*}{\multicolumn{2}{|c|}{ Results }} \\
\hline & \multicolumn{2}{|c|}{$\begin{array}{l}\text { Dependent } \\
\text { variable: quality } \\
\text { level }\end{array}$} & \multicolumn{2}{|c|}{$\begin{array}{l}\text { Dependent } \\
\text { variable: mass } \\
\text { production }\end{array}$} & \multicolumn{2}{|c|}{$\begin{array}{l}\text { Dependent } \\
\text { variable: mass } \\
\text { production }\end{array}$} & & \\
\hline & B & Beta & B & Beta & B & Beta & & $\begin{array}{l}\text { mediating } \\
\text { effect }\end{array}$ \\
\hline (Constant) & .929 & & .836 & & .647 & & & \\
\hline convergence & .205 & $.246^{* *}$ & .337 & $.381^{* * *}$ & .295 & $.334^{* * *}$ & accept & $\begin{array}{l}\text { partial } \\
\text { mediating }\end{array}$ \\
\hline $\begin{array}{l}\text { similar } \\
\text { experience }\end{array}$ & .461 & $.475^{* * *}$ & .241 & $.233^{* *}$ & .147 & .142 & accept & $\begin{array}{l}\text { complete } \\
\text { mediating }\end{array}$ \\
\hline $\begin{array}{l}\text { government } \\
\text { support }\end{array}$ & .117 & $.149^{* *}$ & .198 & $.236^{* *}$ & .174 & $.208^{* *}$ & accept & $\begin{array}{l}\text { partial } \\
\text { mediating }\end{array}$ \\
\hline quality level & & & & & .203 & $.191^{* *}$ & accept & mediating \\
\hline $\mathrm{R}^{2}\left(\right.$ Adjusted $\mathrm{R}^{2}$ ) & \multicolumn{2}{|c|}{$.463(.450)$} & \multicolumn{2}{|c|}{$.387(.373)$} & \multicolumn{2}{|c|}{$.406(.388)$} & & \\
\hline F-value & \multicolumn{2}{|c|}{$37.888^{* * *}$} & \multicolumn{2}{|c|}{$27.737^{* * *}$} & \multicolumn{2}{|c|}{$22.416^{* * *}$} & & \\
\hline Durbin-Watson & \multicolumn{2}{|c|}{1.766} & \multicolumn{2}{|l|}{1.907} & \multicolumn{2}{|c|}{1.864} & & \\
\hline
\end{tabular}

The model of the hypothesis test result is as follows [Figure 2].

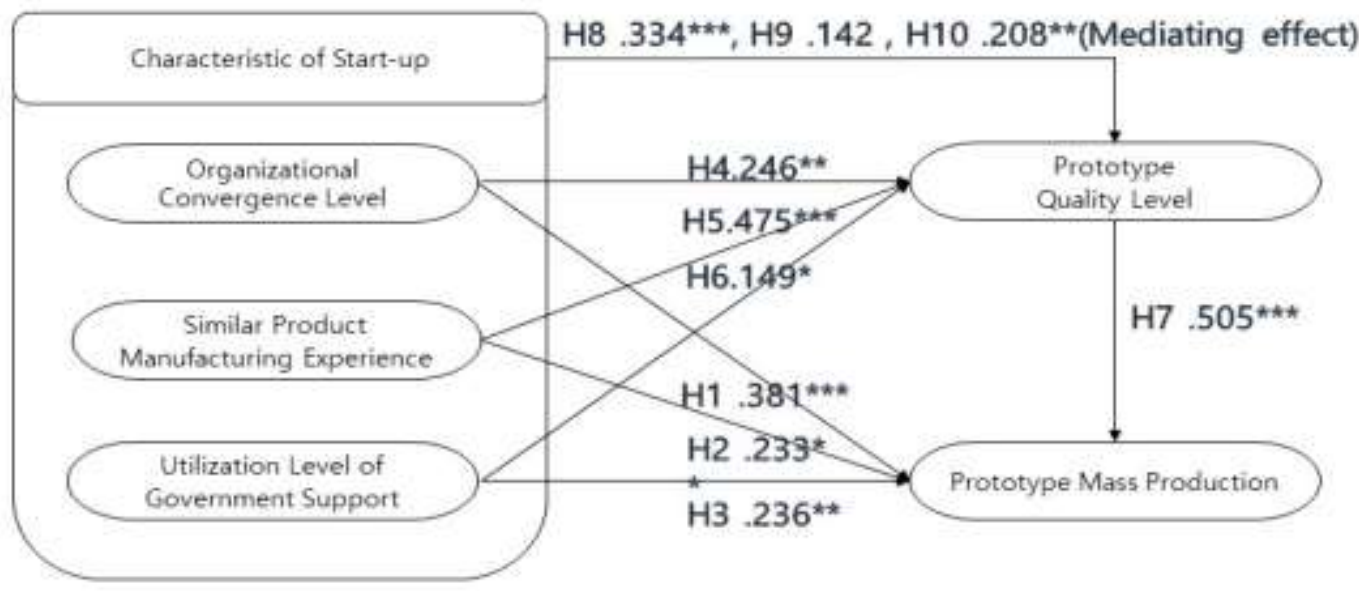

Figure 2 Results of Research Model

\section{Conclusions}

This research was conducted to empirically analyze the characteristic of start-up that influence the Prototype Mass Production. To this end, the Organizational Convergence Level, Similar Product Manufacturing Experience, and Utilization of Government Support were designated as the characteristic of start-up. In addition to analyzing the relationship between characteristic of start-up and prototype mass production, the mediating effect of the Quality of Prototypes on Prototype Mass Production was analyzed. The main contents of the research are summarized as follows.

First, the characteristic of start-up has a significant influence on Prototype Mass Production. The higher the degree of Organization Convergence, the more Similar Product Manufacturing Experience, and the more effective Utilization of Government Support are used, the better Prototype Mass Production, so the owners and employees of the company should strive to develop these characteristics of start-up. In particular, it was confirmed that the Organizational Convergence Level had a higher effect on the Prototype Mass Production compared to other factors.

Second, the characteristic of start-up has a significant effect on the Prototype Quality Level. It was confirmed that the aforementioned characteristic of start-up also influences the quality level. In particular, it was confirmed that the Similar Product Manufacturing Experience has the highest impact on the quality 
level.

When the above factors are closely analyzed, smooth communication between the R\&D department and other departments is helpful for product development, and it is possible to obtain advantages when hiring employees who has experience in the type of business to be developed. and the use of governmentprovided support programs and funds can be inferred that they are helpful to businesses.

Third, The Quality Level of the Prototype has a significant influence on the Mass Production Performance of the Prototype, which partially mediates the Organizational Convergence Level and the degree of utilization of support policies among the internal factors of the company. Furthermore, it was confirmed that the Similar Product Manufacturing Experience is completely mediating the Mass Production Performance of the Prototype. This means that the higher the quality level of the prototype, the higher the performance of mass production, and therefore, efforts are needed to secure the quality level at the time of prototype development.

\section{Acknowledgements}

This research was financially supported by Hansung University.

\section{References}

[1] Yoo SH, Jung DH, Lee GH. Analysis of government-led commercialization support programs. Korea Technology Innovation Society. 2015;69:65-79.

[2] Moogk DR. Minimum viable product and the importance of experimentation in technology startups. Technology Innovation Management Review. 2012;2(3).

[3] Lee HH, Yun H, Gong CH. A Study on the Factors that Determine the Initial Success of Start-up. AsiaPacific Journal of Business Venturing and Entrepreneurship. 2017;12(1): 1-3.

[4] Song M, Noh J. Best new product development and management practices in the Korean high-tech industry. Industrial Marketing Management. 2006;35(3):262-78.

[5] Gupta AK, Wilemon DL. Accelerating the development of technology-based new products. California management review. 1990;32(2):24-44.

[6] Hong JH. Market Orientation, Entrepreneurship Orientation, and New Product Performance in SMEs[Ph.D].[Seoul].The Graduate School of Chung-ang University;2009.

[7] Day GS. The capabilities of market-driven organizations. Journal of Marketing.1994;58(4):37-52.

[8] Sinkula JM. Market information processing and organizational learning. Journal of Marketing.1994;58(1):35-45.

[9] Cyert RM, March JG. A Behavioral Theory of the Firm, Englewood Cliffs, NJ, PrenticeHall.1963;2(4):80-92.

[10] Duncan R. Organizational learning: Implications for organizational design. Research in organizational behavior.1979;1:75-123.

[11] Slater SF, Narver JC. Market orientation and the learning organization. Journal of marketing. 1995;59(3):63-74.

[12] Brouwer E, Kleinknecht A, Reijnen JO. Employment growth and innovation at the firm level. Journal of Evolutionary Economics. 1993;3(2):153-9.

[13] Koski H. Public R\&D subsidies and employment growth: Microeconomic evidence from Finnish firms. ETLA Discussion Papers; 2008.

[14] Piekkola H. Public funding of R\&D and growth: firm-level evidence from Finland. Economics of Innovation and New Technology. 2007;16(3):195-210..

[15] Almus M, Czarnitzki D. The effects of public R\&D subsidies on firms' innovation activities: the case of Eastern Germany. Journal of Business \& Economic Statistics. 2003;21(2):226-36.

[16] Czarnitzki D, Ebersberger B, Fier A. The relationship between R\&D collaboration, subsidies and R\&D performance: empirical evidence from Finland and Germany. Journal of applied econometrics. 2007;22(7):1347-66.

[17] Feigenbaum AV. Total Quality Control, 3rd ed. New York: McGraw Hill;1988.

[18] Juran JM, Gryna FM. Quality Planning and Analysis, 2nd ed. New York: McGraw Hill;1980

[19] Park SH. A Study on the prototype for service design. KSDS Conference Proceeding, Korean Society of Design Science.2011;10:180-181.

[20] Crawford CM. New Products Management, 9th ed. New York: McGraw Hill;2007

[21] Olson EM, Walker Jr OC, Ruekerf RW, Bonnerd JM. Patterns of cooperation during new product development among marketing, operations and R\&D: Implications for project performance. Journal of Product Innovation Management: An International Publication of The Product Development \& Management Association.2001;18(4):258-71. 